\title{
Indigenous health in Brazil: Reflections on forms of violence
}

\author{
Carla Costa Teixeira ${ }^{1}$ \\ Cristina Dias da Silva ${ }^{2}$ \\ 'Universidade de Brasília, Brasília/DF, Brasil \\ ${ }^{2}$ Universidade Federal de Juiz de Fora, Juiz de Fora/MG, Brasil
}

\begin{abstract}
This article concerns public health policies for the Indigenous peoples of Brazil, focusing on relations of violence observed by the authors during their research. We draw attention to different types of violence through an analysis that articulates fieldwork on primary health care in Indigenous Areas with observations of political negotiations concerning health issues involving Indigenous leaders and government workers. There is, on the one hand, the habitual symbolic violence that can be observed in daily interactions between health workers and Indigenous patients, and, on the other, the contradictions of an official political rhetoric that assents to Indigenous authority and then systematically dismisses it when decisions that involve public health are put into practice. The research combines different methodological strategies (intensive fieldwork, research on public policy documents, participant observation of political meetings, interview with indigenes and managers, etc.) to establish correlations between interpersonal violence and structural violence along democratic processes of public policies building in Indigenous health. From this perspective, the paper addresses the violence in health sector beyond the individuals and their intentions; it proposes that violence in health must be interpreted against the backdrop of a broader discussion on the construction of Indigenous citizenship that articulates tutelage and political participation in the politics of health practices in Brazil.
\end{abstract}

Key words: indigenous health; tutelage; citizenship; violence; participation. 


\section{Saúde indígena no Brasil: Reflexões sobre formas de violência}

\section{Resumo}

Este artigo trata das políticas de saúde pública para os povos indígenas do Brasil, enfocando as relações de violência observadas pelos autores durante sua pesquisa. Chamamos a atenção para os diferentes tipos de violência através de uma análise que articula o trabalho de campo sobre atenção primária à saúde em áreas indígenas com observações de negociações políticas sobre questões de saúde envolvendo líderes indígenas e funcionários públicos. Há, por um lado, a violência simbólica que pode ser observada nas interações cotidianas entre as/os trabalhadoras/es da saúde e as/os pacientes indígenas e, por outro, as contradições de uma retórica política oficial que afirma a autoridade indígena e, em seguida, a descarta sistematicamente quando as decisões que envolvem saúde pública são colocadas em prática. A pesquisa combina diferentes estratégias metodológicas (trabalho intensivo de campo, pesquisa sobre documentos de políticas públicas, observação participante de encontros políticos, entrevista com indígenas e gestores etc.) para estabelecer correlações entre violência interpessoal e violência estrutural ao longo dos processos democráticos de construção de políticas públicas na saúde indígena. Nessa perspectiva, o artigo aborda a violência no setor saúde além dos indivíduos e suas intenções; propõe que a violência em saúde seja interpretada no contexto de uma discussão mais ampla sobre a construção da cidadania indígena que articula a tutela e a participação política nas políticas de saúde no Brasil

Palavras-chave: saúde indígena, tutela, cidadania, violência, participação. 


\title{
Indigenous health in Brazil: Reflections on forms of violence
}

\author{
Carla Costa Teixeira
}

Cristina Dias da Silva

This article concerns public health policies for the Indigenous peoples of Brazil, focusing on relations of violence observed by the authors during their research. We draw attention to different types of violence through an analysis that articulates fieldwork on primary health care in Indigenous Areas with observations of political negotiations concerning health issues involving Indigenous leaders and government workers. There is, on the one hand, the habitual symbolic violence that can be observed in daily interactions between health workers and Indigenous patients, and, on the other, the contradictions of an official political rhetoric that assents to Indigenous authority and then systematically dismisses it when decisions that involve public health are put into practice.

We begin by explaining our approach to violence, charting the central historical contradictions of the public policies for Indigenous health in Brazil. A number of ethnographic situations then convey different types of violence, weaving connections between the two configurations and the forms of violence they engender. This is finally interpreted against the backdrop of a broader discussion on the construction of Indigenous citizenship in the politics of health practices in Brazil.

\section{Violence as a quality of interactions and as a structural condition}

One of the greatest challenges to employing the category of "violence" is breaking free of the dichotomy that defines it exclusively through either its representations by the subjects being researched, or its reduction to objective and universal aspects applicable to all sociocultural forms regardless of the meanings attributed by those affected in any given context. While the radical relativism of the former alternative stifles the comparative approach that is so central to anthropological understanding (and to the scientific endeavour), the diversity of configurations that may be presumed violent according to the latter alternative obliges the researcher to choose which local aspects are part of a repertoire that is common to humanity as a whole - a decision that demands an analytically unprofitable exercise in authority.

To free ourselves of the binary dilemma of having to choose between an imposition of the senses that renders the translation between worlds impossible, and the ethnocentric comprehensiveness of empirical universals, we need to take a different tack to "violent phenomena". We can no longer ask what is the content of violence, but rather what characteristics single out a form of interaction as "violent". Violence hence ceases to be a substantive reality to become a quality of social interactions whereby meaning and strategy are anticipated, manipulated and disputed. From this point of view, violence is a resource for the construction of legitimacy for those participating in a specific situation that defies the physical-moral integrity of others (Riches 1986; KrohnHansen 1994, Dias da Silva 2017a). If moral violence does not always involve force or physical pain, all physical violence is also moral violence, for it violates the identity of those who suffer the aggression - that is, his or her representation of their condition and place in the world. It does not matter if an episode of physical aggression is preceded by moral violence; all that matters is that the category of 'violence' enables us to understand and account for connections within the physical-moral universe that we are describing. 
Taken as a conflict of legitimacies, violence emerges in a discursive landscape in which the (political, moral, emotional, etc.) value of actions is in question. It develops within fluxes and temporalities in which opposing subjects seek to favourably position themselves by constructing and construing the validity of their acts. Subjects thus struggle for a redefinition of shared meaning (even when meaning is differentially distributed) that can sustain and ensure a coveted legitimacy; or, in other words, a shared meaning that constitutes the symbolic terrain wherein certain words and values will be adequately managed from the vantage point of each of the terms directly (considered as aggressor and victim) or indirectly (mediating subjects and meanings) involved in the dispute.

Riches' work on violence as a quality of interactions, published in The Anthropology of Violence (1986), along with its posterior developments (Krohn-Hansen 1994; Stewart and Strathern 2002), highlights its structural and invisible dimensions. It aims to articulate the interactional approach with the social and political constraints within which concrete interactions take place by emphasising that violence must be understood through certain formal characteristics. Violence is here a material and symbolic instrument of specific relations of power, where the tacit recognition (the legitimacy) of the world is in question and in which interactional configurations always involve mediations and mediators. We follow this approach not because we are after some sort of conceptual synthesis, but because of the exigencies of the ethnographic experiences that inform this study - to wit, the political relations the permeate recent issues concerning Indigenous health in Brazil which cannot be exhausted by what Farmer (2004:305) has called the ethnographically visible. In a Weberian key, our approach involves a heuristic choice that seeks, on the one hand, to pinpoint the relevance of considering violence as meaningful action, structure and history, and, on the other, to express an affinity with a certain contextual and localized view of the available theoretical options in the social sciences.

In the opening pages of his masterful article 'An anthropology of structural violence', Farmer (2004) stresses the need to articulate the interpretative project of modern anthropology with the historical understanding of the wider social and economic structures in which suffering is located - in his case, suffering emerging from the AIDS epidemic in Haiti. Instead of demanding that ethnographies incorporate historical contexts or surveys, Farmer addresses the challenge of building connections between temporalities and spacialities that are experienced as being disjunctive. He thereby mutually references the meanings attributed to experience and to the materiality of social life. The author aligns stories of the suffering of Hattian patients seeking treatment for tuberculosis, AIDS or cancer, which were "ethnographically visible" to him, with the way of life of the French bourgeoisie in the $19^{\text {th }}$ century, querying its characteristic material conditions of affluence and excess. The critical position he adopts foregrounds the lucrative slave-holding colony of São Domingos, which has today become poverty-stricken Haiti. By triangulating eras and spaces, Farmer renders explicit the deep structure and institutional nature of the violence lived by Haitians in their contemporary quest for therapy. What is more, he shows that this structural violence is perceived as a subjectless and blameless systematic violence which transcends those immediately involved in relations of care (health professionals and patients), thus placing constraints on the possibility of action. This way of perceiving violence is made possible by various forms of de-socializing experiences and worlds, or of erasing historical memory, which the anthropologist must restore lest she understand only the residual meanings of the experiences under study.

If, in Farmer's (2004: 309) terms, material imbalances of power cannot be effaced without distorting meaning (which establishes their relevance to anthropology's interpretative project), in Bourdieu's work we find a near-perfect inversion of this relation. For the latter, the transfiguration of the material relations of power is the hallmark of a specific type of power: symbolic power. Symbolic violence is hence the gentle and invisible form of power, one that becomes more intense whenever direct physical or economic violence is negatively sanctioned by the group (Bourdieu 2002). Through a sort of social alchemy, symbolic violence generates legitimate authority via personal relations in which work, time, attention, care, inclusion, 
political participation, or indeed any other attitudes that are morally attuned to the environment or group, seek to generate a value that is seen to be irreducible to the materiality of the world. Such practices can thereby be seen to be generous, disinterested, and, above all, committed to transcendental ideals (saving lives, strengthening democracy, etc.).

For Bourdieu, the concept of the habitus binds structures and practices through the agency of subjects. While subjects incorporate conduct, they create and recreate modes of acting based on a principle of perceiving ulterior experiences as "a system acquired from generative schemes" (Bourdieu 2009: 91). The habitus seeks to overcome the dichotomies of subject and action, individual and society, structure and practice. It is reminiscent of Schutz's definition of anticipation and typification as actions in the lifeworld: anticipation based on preceding experience (structured structure for Bourdieu) and typification based on classifications or modes of perceiving future experience (structuring structures). According to Schutz (1979: 136), anticipating and typificating are equated in the mediation of past and future experience, which occurs through a subject who acts according to a relevance system created by and through him or her. The acting subject is the link, he or she maintains the unity of the oppositions. If we return to the symbolic violence (understood as a quality of interaction) of the habitus, we can reflect on violence as its own universe of mediation between action and structure; or even as a third possibility, a kind of social grammar that furnishes specific rules to a game in which the struggle for legitimacy itself legitimizes the dispute over meaning. Violence is hence made legitimate as a part of interactions. However, such a grammar is constituted through a historical process in which material imbalances of power have combined forms of physical and symbolic violence in different ways.

\section{Policies for Indigenous health in Brazil: between abnegation and degradation}

Studies of the history of health policies for Indigenous peoples in Brazil reveal an apparent contradiction, which probably dates from the very first acts of government intervention, between the "abnegating motivation" of the health workers and the "structural dynamics" of a contact that leads to the physical degradation of the Indigenous populations (Costa 1987). Government involvement in Indigenous health only developed into formal assistance in 1956, almost 50 years after the creation of the Indigenous Protection and National Worker Placement Services (Serviço de Proteção aos Índios e Localização dos Trabalhadores Nacionais, SPILTN) in 1910. In 1918, the SPILTN was remanaged as the Indigenous Protection Service (Serviço de Proteção aos Índios, SPI). The sanitarian Noel Nutels was fundamental in the planning and execution of what was termed the Aerial Sanitary Units Service (Serviço de Unidades Sanitárias Aéreas, SUSA). This was one of the first of successive efforts, taking place throughout the 2oth century, to intensify sporadic treatment and to improve our knowledge of the health conditions of Indigenous populations. Previously, information on Indigenous health was only occasionally transmitted through the reports of missionaries and doctors who took part in expeditions into the Brazilian interior (Costa 1987: 391).

Having taken part in the Roncador-Xingu Expedition, Nutels also believed that it was necessary to safeguard means for ensuring the survival of groups. An equally important task was to mediate recent contact with other groups, so as to prevent deaths from endemic and fatal cases of tuberculosis, malaria, the flu, and other diseases ${ }^{1}$. After the expedition, Nutels strove to set up a system of continuous care, undertaking a specialization course in tuberculosis in order to establish permanent control over the disease. Treatment of this disease in particular, following the sanitary procedure of isolating areas where the disease has spread, would continue to be a part of the strategy of thehealthservices even after the dissolution of theSUSAin1968. In thewords of Nutels(in Costa1987:392):

1 See Cunha's (2002) interesting study of the "spirit of sanitary policies" based on reports by health professionals published in the 1930 in Brazil. 
"This way we will establish a veritable sanitary curtain around the affected area. No one will be able to enter with prior control".

We can conjecture that attempts to prevent the spread of disease, with their focus on isolation and territorial control (inspired by the philosophy of Rondon), was forged in the heoric aura attributed to the health teams that assisted Indigenous peoples in the most remote places. In a recent study of the sociological history of public health in Brazil, Arouca and Lima (2014) have highlighted further contradictions through an analysis of the 1947 medical plans for Indigenous peoples. The author of the document, Dr. Herbert Serpa, already identified a clash of conceptions: "the profound differences and divergences that exist between Indigenous medicine and that of civilized men is undeniable..." (Arouca and Lima 2014: 70).

Comparing conceptions of indigenist policy seems to us to be a pertinent aspect of the analysis of these early state-sponsored instances of healthcare for Indigenous peoples. Indeed, these first instances of medical aid may be considered the first manifestation of tutelary powers in what pertains to the field of health in Brazil. From the outset, the authoritarian heroism of the health professionals - and of the indigenists in general - and the drama of the expansion of Brazil's internal frontier (Velho 2009a, 2009b) were two aspects of the same process.

With the creation of the National Indian Foundation (Fundação Nacional do Índio, Funai) in 1967, and the subsequent establishment of its health division, the healthcare of Indigenous peoples was dismembered and dispersed throughout the national territory. It was no longer a Service (SUSA), but a working group. Through the resources of Funai, an Itinerant Healthcare Working Group (Equipe Volante de Saúde, EVS) was created, made up of a doctor, a nurse, a biochemist and a dentist, all of whom resided in the main regional capitals and occasionally visited Indigenous villages. The earlier model championed by Nutels continued to exist, though Funai put it through an institutional transition by first implementing a rotating system of nursing assistants in the villages, then proposing targeted emergency action and prolonged treatment (Verani 1999: 3), and finally arriving at the present organization. Healthcare thus always focused on basic care and on the removal of critical cases to nearby hospitals. However, it was only after these transformations that the roles of "assistant", nursing technicians and various health adjuncts would be expanded. A structure for providing care was thereby formed. It would outlast the numerous institutional upheavals and crises of legitimacy which affected the politics of Indigenous healthcare during the subsequent decades. The culmination of this fraught process is the model of the Sanitary Districts ${ }^{2}$, premised on social control.

When Nutels coordinated health campaigns, the dominant view of Indigenous health was that it was intimately linked to the evils of contact, spurring the protectionist reaction to safeguard the physical existence of Indigenous peoples through direct intervention. Yet the image of a "sick Brazil" (Lima e Hochman 200o), with its forsaken interior and hinterlands, devisted in the heart of the sanitarian movement of the early $20^{\text {th }}$ century, did not take Indigenous peoples into account. The reports and studies of that time projected an image of a country "with an unknown, backward, ill, unproductive and abandoned population, lacking any identification with the country" (Lima \& Hochman 2000). During the 1940s, this scientific movement established the political and administrative bases for the development of national services aimed at combating endemic diseases that were seen as obstacles for national development. Despite a lack of concern with ethnic differences, the same period also witnessed the emergence of an explicit alignment between the "expansion of public power, development, institutionalized public healthcare, and Indigenous populations" (Hochman e Silva 2014). The focus on disease that characterized the health campaigns was based on this model of government intervention, inspired by conceptions of national and economic development typical of the 1950 and 1960 .

The heroic narrative pursued by a few, sporadic but persistent health professionals thus enhanced the idea of care (assistance) as protection and tutelage of those who were relatively vulnerable and defenceless.

2 See Athias \& Machado (2001), Magalhães (2001), Marques (2003) Buchillet (2004), Rocha (2007). 
The zeal to control exogenous diseases such as tuberculosis characterised a practice of control that focused on "diseases of contact". The growth of the pharmaceutical industry after World War II, with the expansion of antimalarial and antibiotic medication (Hochman e Silva 2014), strengthened the ties between health and development. Although a distinction between combating disease and providing healthcare was maintained, it is evident that disease control through the creation of healthcare working groups targeting Indigenous peoples gradually fed into a logic of practice in which control of people's behaviour, via (epidemiological) campaigns and measures promoting hygiene, resulting in a relation of mutual determination between indigenism and sanitary policies. This is the case whether we are dealing with the Aerial Sanitary Units Service or the Itinerant Healthcare Working Groups. As Arouca and Lima (2014: 76) note, "the 1940 and 1950 s represent an important chapter in the history of the Indigenous question in Brazil; a meeting point between medical conceptions and anthropological perspectives". It is precisely by means of the articulated management of territory, health policies and education that cultural differences were invented as an obstacle to measures of prevention and assistance, giving rise to practices of symbolic violence which deauthorized the other - in other words, to the exercise of a specific tutelary power (Souza Lima 1987). The deauthorization of the other took on a distinct shape after the democratic process which began in the late 1980s, as will be seen below.

Certain facets of the history of indigenist policies in the 2oth century thus invite us to reflect on the connections between the ideas of protection and tutelage which regulate the relations between State and Indigenous peoples, and the expansion of biomedical power in Brazil following the sanitarian movement. The successive restructurations of Indigenous (and, indeed, national) healthcare services, which intensified in the 1950 s and 1960s, as well as in the 1980 s and 199os, in conjunction with internal colonization drives that were typical of the "march to the West" (1950s) and the development projects of the military government (1970s) and subsequent democratic governments (1990s)3. We can discern historical continuities between state services' logic of saving lives and the physical violence of land disputes and conflicts. According to Souza Lima (1987), the words and deeds of the indigenist project augmented political struggle through the entailment of an emergency - no less than the very physical survival of the Indigenous peoples of Brazil - which determined the type of social relation that was to be established. This way of relating time (emergency) and political action (physical survival) was to have a profound impact on Darcy Ribeiro's argument for a government policy that would lie at the interface of protection and tutelage. At the time, both were apprehended as, simultaneously, an urgent drive to save lives and as a form of relation. Darcy Ribeiro thus argued for "the importance of practice, of direct coexistence, of the denial of a scientific posture, of the prophetic vocation for formulating an indigenist project and a project for the nation" (ibid. 1987: 157). This view could easily be generalized for most Brazilian intellectuals. Analysing the work of Darcy Ribeiro, we can discern the constitution of an indigenist project similar to that of Rondon, articulated with an authoritarian view of the construction of nationality. In any case, what fell to the Indigenist Agency, whether the SPI or, later, Funai, was the matter of how to construct this nationality by ensuring the physical preservation of Indigenous peoples, in the hope that this would drag along with it a "desirable cultural survival". Indigenous peoples had nothing to add to the nation other than their own physical existence:

this historically constructed representation is induced by the very structure of this field of struggles that was established at the start of the century by the Brazilian state, resulting in the creation of the SPILTN as an agency. At its core lies the search for a consensus from which, once a position is reached that dodges the censorship that characterizes the field, there will emerge the dimension in which the deeper regions of consensus can be achieved (Souza Lima 1987:163).

\footnotetext{
3 The logic of development is updated in the 20oos, with the rise of large-scale projects linked mostly to hydroelectric power and mining. However, this surge has its paradoxical side, since it is concurrent with the increase in Indigenous participation in the political spheres. We will return to this paradox shortly.
} 
If we are to bring this matter up to date, the question that needs to be addressed concerns, precisely, the new terms in which, to borrow the words of Souza Lima concerning the SPILTN and the myth of Rondon, we can give continuity to "the search for a consensus from which, once a position is reached that dodges the censorship that characterizes the field, [so that] there will emerge the dimension in which the deeper regions of consensus can be achieved". What are the forms of censorship that constrain engagements between indigenism and sanitary policies in these democratic times?

\section{Settings and Violence}

To answer these questions, we will now turn to ethnographic reports pertaining to the two contexts that we have been focusing on: Indigenous political activity at the federal level and health care in Indigenous villages. Our aim is to trace connections between the two. These connections have been rendered invisible, but they seem to us to be crucial channels for comprehending the violence and the power configurations that are characteristic of the public space of Indigenous health.

\section{Negotiations and political setting:}

Institutions reply: [...] we're here to show you discourse is within the established order of things, that we've waited a long time for its arrival, that a place has been set aside for it - a place which both honours and disarms it; and if it should happen to have a certain power, then it is we, and we alone, who give it that.

Foucault, Orders of Discourse, 1971: 8.

Foucault's imaginary dialogue in his reflections on discourse as a dispositif of power guides our understanding of the ethnographic situations that follow. We can convey to the reader our uneasiness at what was said, what remained implied between the lines, what was emphasised, and what led us on the interpretative path that determined how we present the following case studies ${ }^{4}$. Taken as a set, these ethnographic vignettes provide the framework for a more detailed analysis, which will be developed shortly. We hope that this approach allows the reader to grasp what enticed us to write this article, based on research carried out over ten years ago.

\section{Situation 1}

In interviews to Ferreira ${ }^{5}$ carried out in Brasília, two presidents of the District Council for Indigenous Health (Conselho Distrital de Saúde Indígena, CONDISI) explained why their decisions failed to be implemented by administrators:

"[...] the CONDISI has to be called when it's time to make decisions. Now it's only called by the administrator when problems need to be solved with the Indigenous population" (Ferreira 2012:105)

\footnotetext{
4 Except for "situation 1", all of the ethnographic situations presented in this section derive from direct observation and interviews carried out by Teixeira and her team during the 5 th National Conference of Indigenous Health. They are available in the ethnographic film "Estive em Brasilia, lembrei de você" ("I was in Brasília and thought of you") [https://vimeo.com/126372482].

$5 \quad$ Ferreira interviewed 32 presidents of the District Council for Indigenous Health during 2011 and 2012. "The presidents that were interviewed answered the following questions: How was the District Council for Indigenous Health created in your district? What are the main difficulties and significant headways related to social control?" (Ferreira 2012: 12). Interviews were held during the following events: Meeting on Social Control/Mato Grosso do Sul (Reunião do Controle Social/MS), March 2011; Indigenous Health April (Abril Saúde Indígena), April 2011; Free Land Camp (Acampamento Terra Livre), May 2011; Strategic Planning Workshop (Oficina de Planejamento Estratégico), February 2012; Forum Reunion (Reunião do Fórum), March 2012 (ibid: 73 ).
} 
“[...] because today the administrator doesn't respect the deliberations of the council, he pretends that he doesn't know, [...] puts it off, you know? So, like, it's not going to get better, the council can be able, the council can be functioning, but if the administrator doesn't respect it then there's no way things can get better" (Ferreira 2012:85)

\section{Situation 2}

The scene is the opening of the $5^{\text {th }}$ National Conference of Indigenous Health (Conferência Nacional de Saúde Indígena), at a convention centre in Brasilia. The session was composed of government authorities and indigenous leaders, and the audience was made up of over one thousand Indigenous delegates from the whole country. Presentations and tributes were underway when the delegation from the state of Mato Grosso do Sul quietly made its way into the hall, carrying banners with slogans such as: "Indigenous health in Mato Grosso do Sul needs help", "Land is health: urgent demarcation of Indigenous Lands", "Special Indigenous Sanitary District/MS of 75 thousand Indians demands respect: down with the dictatorship in Indigenous health". Some Indians applauded, but the opening ceremony remained indifferent to the manifestation. Sônia Guajajara, coordinator of the Articulation of Indigenous Peoples of Brazil, the first Indigenous leader to speak at the session, drew attention to the message of the Mato Grosso do Sul delegation. To much applause, she condemned the confrontations between Indians defending their lands and the Agribusiness farmers (ruralistas), calling on the Minister of Health, who was present, to "take our call for land to President Dilma". (Field notes, $5^{\text {th }}$ CNSI, 2-6/12/2013, Brasília).

\section{Situation 3}

"Maybe one of the biggest gains, among the many gains we had with the Subsystem [of Attention to Indigenous Health], was, without a doubt, the creation of social control in Indigenous health, which for us has been like a school for many of our Indigenous leaders, with a more concise education in relation to legislation" (Interview with Uwira Xakriabá, president of the District Council of Indigenous Health of Altamira/PA, ${ }^{\text {th }}$ CNSI, 2-6/12/2013, Brasilia).

\section{Situation 4}

"What is the role of a conference? As the name says, the conference confirms $s^{6}$. [...] It evaluates standing policies, detects what is right among them, sees which proposals don't apply and need to be reformulated and approves directives for a new policy or the revision of a standing policy. [...] [Indigenous people] are very well prepared to demand their rights. This is what social control is: participation, respect for others, knowing how to listen, talking less and listening more, seeing out commitments, making deals, negotiating, dialoguing”. (interview with Antonio Alves, Special Secretary of Indigenous Health, Ministery of Health, $5^{\text {th }}$ CNSI, 2-6/12/2013, Brasília)

These situations and interviews took place in formal meetings on the role of so-called "social control" in Indigenous health. More specifically, they took place in the Forum of Presidents of the District Councils for Indigenous Health (CONDISI), which takes place regularly in Brasilia; and the $5^{\text {th }}$ National Conference on Indigenous Health (CNSI), which took place in 2013. These events were chosen because they are legally

6 Translator's note: in Portuguese, A conferência confere, a play on the double meaning of the portuguese verb conferir which means both 'to confer' and 'to confirm'. 
sanctioned meetings of Indigenous leaders, and because of their remarkable capilarity. There are 34 District Councils throughout the national territory, including local councils for villages, a council for each district, and the forum for their presidents, which meets four times every year. Conferences are more irregular, but they gather an increasing number of "delegates" and members of Indigenous organizations from every part of the country. In the last conference, in 2013, more than one thousand Indigenous delegates were present. But the determining factor was that social control, of which these organizational levels are a part, was the primary focus of the permanent political activity of participating Indigenous peoples in what concerns health policies. This emphasis was sustained throughout the 200os, at least until President Temer came to power in 2016. In the situations presented in this article, Uwira Xakriabá explicitly said that social control was a "school" and one of the greatest gains in the field of Indigenous health policies (Situation 3 ) - which ratifies what we heard between 2006 and 2014 in the regular meetings of the Intersectional Committee for Indigenous Health. Understanding this policy not only stresses its importance for Indigenous peoples, but also places it in the sphere of academic debates on social participation as a form of government. By focusing on it, we seek to reveal the symbolic violence that this process of democratic expansion appears to actualize.

The situations presented above reveal a complex and singular political game, in which the participation of Indigenous representatives or leaders, even when this participation is critical of the proceedings, is recognized and often praised. Their voices are integrated with those of government authorities in conferences and in the local administration of the 34 special districts for Indigenous health - whether as participants in the district councils, as indigenous advisors for administrators or as health agents. Trimesterly meetings are held with all of the presidents of the district councils for Indigenous Health in the Ministry of Health in Brasilia, and Indigenous representatives have a seat in the National Health Council, which is the central agency for participative deliberation in health policies. They coordinate and compose the majority of the inter-sectorial comission on Indigenous health (a commission that assists the national council in matters pertaining to Indigenous health), and participate in other commissions that provide assistance to the national council. This inclusion is attested in the four situations, but it coexists with a feeling of powerlessness 7 . But powerlessness does not deauthorize the democratic rhetoric of participation as a form of government - which was a hallmark of the governments of President Lula and President Dilma Rousseff. However, it euphemizes the degrading living conditions and growing physical violence in Indigenous territories (we will return to this shortly).

In the interactions presented above, we can glimpse the production of symbolic violence in tangential complaints and accusations, along tortuous paths. In these paths, the legitimate authority formally conferred on Indigenous leaders and representatives by means of the policy of social participation is reduced to contexts such as the health conferences and national and district councils, where principles and injunctions for national and Indigenous health policies are discussed and deliberated and where they are tracked across different levels. From this point of view, participatory politics, as it is structured: (1) institutionally excludes from Indigenous authorities the exercise of local and national health policies and, at the same time, (2) keeps their voices close to the administration as consultants and advisors (for example, in relation to the special secretary of Indigenous health in the Ministry of Health, and to the directors of the Special Indigenous Sanitary Districts throughout the country). In this configuration, Indigenous presence is de jure instituted, but defacto deauthorized. However, Indigenous peoples tend to place blame on the individuals with whom they interact in administration: it is these men and women who neglect their opinions. The alchemy that makes violence invisible within this configuration is conjured through the transformation of the rules of the political game into a matter of personal character: local administrators do not respect the deliberations of the councils, as voiced by the presidents of the CONDISI in Situation 1. National administrators meanwhile listen to the positions and recommendations of the

\footnotetext{
7 Data gathered by Ferreira (2012: 85) confirms this hypothesis: "In the questionnaire, when replying to whether the demands of the Indigenous peoples were met in 2009, half of the 34 Condisis provided a negative answer, 8 provided a positive answer, 8 claimed that they were partly met, and one did not reply".
} 
advisors in the national conferences, but their opinions on health and land are not taken into consideration, if they make their way to the presidency at all. As of to confirm this posture of listening without attributing authority to what is said and done, we have the incident narrated in Situation 2, when government authorities in the opening solemnities of the $5^{\text {th }} \mathrm{CNSI}$ ignored the protests of the delegation of the state of Mato Grosso do Sul. And, again, the Special Secretary for Indigenous Health confirmed his office's vocation for the pacification of conflicts during conferences, which, in his words, involve "knowing how to listen, talking less and listening more, seeing out commitments, making deals, negotiating, dialoguing" (Situation 4).

We can thus observe that, by being glossed as "democratic administration", the exercise of daily domination, which is proper to bureaucracy (Weber 1999), comes to be attributed the moral qualities or political and material interests of administrators. Administrators are therefore accountable for not putting into practice the guiding principles agreed in common for Indigenous health policies. We do not intend to imply that individuals do not matter in the exercise of functions, whether bureaucratic or political. What we wish to stress is that the emphasis placed on this dimension inhibits us from seeing that it is the very model of political participation and its institutional conditions that make it legitimate for Indigenous peoples - who are already excluded from formal legislative instances and from top-level decisions on the distribution of resources, as well as from the equally important networks of personal relations that influence those in power - to also become excluded from the daily administration that reproduces, accommodates and readapts the dominant material and political relations of power.

This exclusion is tacit in the game of participative inclusion. It is expressed as 'disrespect' that is anticipated and typified in interpersonal dynamics through a moral vocabulary of negotiation, compromise and dialogue (Situation 4), the ultimate effect of which is to deauthorize the conflicts of legitimacy that qualify accusations of violence. In this way, the central dispute, which involves the external conditions that limit participation as a political strategy, is relegated to a secondary concern. In other words, any reflection on the terms whereby the rules of the game are defined, which establish what can be said when, by whom, and in which politicalinstitutional contexts; as well as on the place of the game of 'participation' in the hierarchy of the politicalinstitutional contexts and the effects that are produced by inhabiting this place, is banished by the cardinal value attributed to the mechanism of participation itself (by both Indigenous peoples and authority figures, Situations 3 and 4). It is also banished by the privilege given to internal relations of power between the subjects that make up the participative arenas: the accusations against administrators by the presidents of the CONDISI, and the repercussions of the lack of consequences stemming from the protest in the opening session of the $5^{\text {th }}$ CNSI (Situations 1 and 2 respectively).

It is clear to Indigenous representatives and leaders that safeguarding Indigenous territories is paramount for improving the health of Indigenous peoples ${ }^{8}$ (as, indeed, the delegation from Mato Grosso do Sul ritually enacted at the $5^{\text {th }} \mathrm{CNSI}$, Situation 2). It is equally clear that other forms of political action matter, ones which eschew the entrapment of the "discourse of administration", and which build on autonomous political strategies, such as the Free Land Camp (Acampamento Terra Livre), which has taken place in Brasilia every April since 2003 (Souza Lima 2015; Silva 2017). What is less clear (and this is not specific to the Indigenous movement, nor to Brazil; see Bronz 2016; Cruikshank 1999), is that the game of participation contributes to the political resignification of the direct violence experienced locally, and, above all, to the existing estrangement of the political and economic dimensions. It is as if the attacks on Indigenous territories by large landowners - represented in Congress by the "Parliamentary Group for Agribusiness" - occurred in spite of the Indigenous presence in national politics and the democratic project that is expressed by this presence. They thus appear to be isolated and exceptional episodes, which should be investigated and settled as if they were criminal cases.

8 For those who want to read further, see the reports of the National Conferences for Indigenous Health (http://conselho.saude.gov.br/biblioteca/relatorios. htm). Viewed on 20/01/2018. 


\section{Negotiations and scenes of healthcare in the villages 9}

Before turning to the second set of ethnographic situations, it is important to explain that the health posts situated in Indigenous villages are one of the so called "limits" of the subsystem of Indigenous health. Following the logic of decentralization implemented through the 34 sanitary districts, the health post is imagined as the starting point - that is, where patients begin their journey along trajectories of healthcare through institutional health policies. Rather than setting up a comparison of objectives and results, we propose to focus on the routes available for those who seek consultations, medication and guidance for various ills, such as diarrhoea, headaches, stomach aches, fevers, malaria, flu, pneumonia, and so on. The medical interventions that can be carried out in these posts do not go beyond the administration of medications, consultations or, at best, small sutures. The posts, although viewed as appealing "ports of entry" into the system, are often spaces where intense crises involving varied subjects takes place. Death by negligence or lack of basic conditions for providing treatment can occasionally, and circumstantially, be experienced as individual errors. It is this type of power that we want to investigate here.

The following situations describe multiple levels of symbolic violence (which is said, heard, witnessed, felt). Due to the fleetingness of their frameworks, these levels of violence can best be apprehended through concrete situations. Thus, the mundane act of applying an injection (Situation 5 ) can unfold into an unrelenting cascade of neglect - engendering, in one fell swoop, the lack of material structure and the interactional configuration that takes place in health posts in Indigenous villages. Even when there are explicit critiques of the visible poverty of villages, material lack is conveyed as an equally moral facet of repulsion toward the values and practices associated with the Indians, although not only with them. Certain episodes originating in an ethnography of the DSEI Rio Tapajós, carried out in 2008-2009, exhibits this dynamic.

\section{Situation 5}

“This afternoon I went with nurse Malu to another visit/consultation at Mrs. Kabá's house. She was strewn across her hammock with a stomach ache. Nurse Malu immediately asked if she wanted to travel downriver, to town, but Mrs. Kabá simply said she didn't. The nurse then stressed that Mrs Kabá was responsible for her own decision to stay in the village, and that she [nurse Malu] would be travelling to town the following day. If something were to happen to her, "if you, God forbid, were to die, you wouldn't have anyone to attend to you". Mrs Kabá ignored her advice. We all shifted to a part of the house that had better light, to give the patient an injection. Malu asked if she'd eaten, but she hadn't. It was already 2:30PM. Malu decided: "So it's wind in your belly. That hurts. You have to eat". She started to look at the children around her and pointed to one of the boys, who had a bone deformation in his ankle, and asked if they had applied for his retirement. She also observed that when he had arrived from Jacareacanga the boy had been fat and that he'd lost a lot of weight in the village. When we left, she quipped that there were too many children in that house and that Mrs. Kabá's sons did nothing. To prove her point she referred to one of them, who had been resting when we arrived at the house".

What stands out from this vignette is that the nurse, who is well-known locally, and who was somewhat respected by the Munduruku because of the time she had spent working with Indigenous health, nonetheless failed to put together a credible dialogue. Malu could not possibly have believed her own words when she said that the injection would have helped to cure "wind in the belly"; at the very least her training as nurse would immediately preclude that possibility. What we claim here is that her words were a rhetorical choice

9 Situations 5, 6, 7 and 8 were experienced by the anthropologist Cristina Dias da Silva during her doctoral research, between 2006 and 2010 . The thesis which resulted from it is included in the bibliography. The first person singular here refers to this fieldwork in particular. 
in relation to her Munduruku interlocutors. Metaphors such as "wind in the belly" are a typical means of discrediting the other, as attested in a number of anthropological studies of tutelary power and its many facets, such as, for example, studies in the medical anthropology of the power relations that permeate instances in which doctors/health professionals and patients talk past each other when they come from different cultures (Garnelo 2003 e 2004, Langdon 2004, Cardoso 2004, Smiljanic 2008, Novo 2010, Teixeira 2012, Ferreira 2013), or from distinct social groups (Boltanski, 1979, Loyola 1984, Dias Duarte 1986). What is in dispute, it seems, is not an opposition between biomedical and traditional knowledge. What is in dispute in these interactions is not epistemic reason, but rather a capacity to navigate "difficult" situations, or, as nursing assistants often say, of "giving it your best shot".

\section{Situation 6}

"An explicit and common means of avoiding conflict in day-to-day interactions involved administering vitamins. Of the many medications kept in the post, it was poly-vitamins, B vitamins and vitamin C that were usually administered to pregnant women, malaria patients in recovery, and also - surprisingly - "to avoid conflicts". Practically, this meant patients without any symptoms, who were only after attention, could eventually be prescribed vitamins, in an act of basic reciprocity. The fact that the register in itself is a mere informality reveals a stable pattern of conduct and interactions. Typically, more experienced professionals had recourse to this method, which was considered mostly harmless. Associating vitamins with various strategies for avoiding conflict stems from an analysis of the specific contexts that one experiences and lives in the field alongside health professionals and the Munduruku. For the former, the improvised aspects of health care were not evidence of a "lack", but a total way of acting, a way of being within the subsystem of Indigenous health. Hence the importance of approaching improvisation as a native category, as discussed elsewhere" (Dias da Silva, 2014).

\section{Situation 7}

During an interview at the local headquarters of DSEI Rio Tapajós in Itaituba (Pará State), Mr. Lino, who was responsible for sanitation work in the District, and a long-time employee of the agency, explained to me that sanitation development was going ahead. Their priority that year was to finish projects that had been abandoned along the way, such as the piping for the village where I was residing, which had faucets, bathrooms and kitchens, but no water. This situation persisted for over ten years. He hoped to travel to the village before the year was over.

When I returned to the field in the second half of 2009, piped water had finally been established in the village: "The establishment of piped water in the village, after so many years, made access to water much easier, but people nonetheless continued to walk down to the river every day to bathe, wash clothes, was dishes. The village bathrooms (which also had faucets and two showers) were not used regularly. In the afternoon, many children took baths in these "sanitary improvements" and a pet tapir, which belonged to an old woman who lived next to the post, would often occupy the space in the mornings, enjoying the humidity of the tiles, much to the amusement of the children. The faucets in each house were built into a basin, but these had incomplete piping. The water would fall directly to the earth, in the exterior of the house. Bathrooms had cesspits. Piped water had no effect on the times when people would gather on the river banks. Families would gather to go to the river." 
In a "lifeworld", to use Schutz's general expression for describing the flux of events, where we find the cohabitation of sanitary installations, tapirs, health professionals, medications, the river, and so many others, material diversity is as epistemic as any other articulatory concept. Conceiving of this scene as a 'situation' requires a conceptual game between structures, as described previously when we discussed symbolic violence as a form of interaction.

\section{Situation 8}

"In the very first week [of fieldwork], a nurse held a lecture for mothers on "Sexually Transmitted Disease, Cervical Cancer Prevention and Hygiene". Although she invited an Indigenous health agent to translate the lecture, she began before he arrived, despite the fact that most of the Munduruku women do not understand Portuguese. When the interpreter finally arrived, he always translated long stretches of speech, accompanied by images displayed to the audience, without being afforded a suitable amount of time for translation".

In the economy of values that makes up the institutional engineering of Indigenous healthcare in Brazil, the Indigenous health and sanitation agents, along with nurses and nursing technicians, occupy a privileged place. They provide the link between the Indigenous community and the health professionals, particularly in what pertains to facilitating articulations between traditional indigenous practices and biomedicine. This mediation should ensure the recognition of ethnic and cultural specificities during health care, what is known in Brazil as "differential care", thus enabling the subsystem of Indigenous health to promote and recover the health of Indigenous peoples, advancing the exercise of full citizenship. Theirs is an institutional function, which, from the start, comprehends a technical and political orientation. However, attention to the daily practice of care in Indigenous areas (situations 7 and 8) reveals the distance between the "language of imagination" characteristic of normative documents and the "language of decision" that these types of texts look to enable (Geertz 1985). This distance, as the situations above express, is constituted in the myriad relations of neglect toward patients and Indigenous agents, observed in the day-to-day of the village (Dias da Silva 2010; Situations 5 and 6), in what concerns culturally differentiated care, the demands of patients, and the mediating role of Indigenous health agents.

The metaphor of "wind in the belly" (Situation 5) can be described as a redundant situation. Pretty much every day had its "wind in the belly" moment, or one of "vitamins to avoid conflicts" (Situation 6). Even though the nurses and health technicians are the professionals of the subsystem of Indigenous health who are closest to the experiences of pain and suffering of the Munduruku people, they are also generally capable of perpetrating a type of deauthorization which is difficult to understand, for it does not emerge as a form of coercion, nor was it driven by evil intentions - quite the contrary. It is a form of violence which authorizes and deauthorizes in equal proportion: it blames the Indigenous patient (and her family) for their condition, holds her accountable for the consequences of her decision to stay in the village, and, at the same time, ignores the political dimension of (for example) the precarious material conditions of healthcare available in the subsystem. It thus reveals tutelary power in its brutal form, rather than in the benevolent form that we usually observe. The manner in which people (as "patients and their families") were treated recalls mechanisms of deauthorization as a type of interaction that avoids conflicts, but which has a potential for conflict that inhabits this very avoidance. This process evokes Herzfeld's (2008) approximation of the concept of violence to the notion of cultural intimacy, which he provisionally defines as a sort of disseminated essentialism expressed in practical constraints in social life: "cultural intimacy is, above all, familiarity with known social imperfections, which provide culturally convincing explanations for apparent deviations from public interest" (Herzfeld, 2008:24-5, our emphasis) 
These mechanisms of deauthorization are also visible in the prescription of medication (Situation 6), where the potential for conflict that might emerge from a visit to the post that does not result in the dispensation of medication was countered via the oral administration of vitamins. This is one of many possible situations: it is exemplary, but not absolute. "Complaints" deemed to be exaggerated, but which could not be ignored, were managed, relatively successfully, through this use of vitamins as a substance/object that hovers over a certain perception of cultural distance ("they do not understand" or "do not know", evaluations typical of tutelary power). To claim that vitamins occupy a privileged place in the daily regulation of conflicts, being interpreted through native categories of improvisation, does not lay blame on individuals for the actions associated with them. Our aim is, rather, to understand these specific acts as part of a wider set of attitudes and tactics, as suggested by the notions of tutelary power and inequality (Souza Lima,1995; 2002a, 2002b, 2002c).

This singularity of vitamins, which made them stood out among the range of available medication, makes explicit the persuasive potential of acts of "administering medication", which is even more interesting for being a performative act, a ritual of daily interaction. The political/ritual dimension of this relation also emerges in the case of water supply and sewage in the village (Situation 7). The faucets had been a part of people's homes for many years. On the one hand, this reveals the precarity of services rendered. The scene was, at best, strange: faucets with no purpose, piping that was defective before being used. On the other hand, when the sanitation work was complete, Munduruku use of the faucets "fell short of expectations", a type of explanation which points to meanings other than material precarity. In this case, we draw attention to the fact that, from the perspective of structural precarity, precarity itself is transformed into relations of tutelage - that is, into efforts to control the behaviour of another who is considered relatively incapable. This situation contains a form of interaction that we have sought to underscore: the material conditions acquire a double meaning, they perpetuate and represent. They afford continuity to flagrant problems, while also coming to represent the other through an inversion between living conditions and ways of living Dias da Silva 2010). ${ }^{10}$

In Situation 8 the nurse focused on the expressive force of her lecture through a logic that neglected the actions of the Indigenous agent. The notion of risk and danger that the she transmitted through the pictures of disease were considered fundamental means of connecting with the audience, part of a purportedly universal discursive strategy. She then shifted from warnings to "risk management" by drawing attention to actions that modified self-care for the sake of disease prevention. In what concerns hygiene, the link between warning and behavioural prescription was evoked by reference to the Amazonian winter, which was just starting at the time, and the diseases linked to river water that proliferate during this season (mostly diarrhoea and worms). She stressed that it would be wise to "bathe every day, in the morning, afternoon and at night, to clean the house, sweep it, gather trash at the allotted place". The nurses' recommendations included very general and sociologically empty commentary, which made little sense to Munduruku everyday life. Indeed, bathing three times a day and sweeping their homes were common practice. The idea that they defecated on the river banks had no connection to village life, but was rather part of the health education of riverine communities in general.

This vignette is furthermore exemplary for describing an event in health education that did without the Indigenous agent. The nurse lectured in Portuguese to women who were monolingual in Munduruku, without the required translation, using a universalist biomedical language of disease riddled with particular anticipations. Biomedicine is, after all, a cultural idiosyncrasy like any other, whence the emergence of the notion of 'interculturality' as a resource for enabling dialogue between medical knowledges. However, the Munduruku way of life is deauthorized in this process: the health policies affirmed in the Constitution of 1988 ,

10 The concept of 'culture', taken as an obstacle, brings us to a well-known field of tensions between anthropologists carrying out fieldwork and health professionals in sanitary districts. See also Smiljanic (2008). 
and reaffirmed in the meetings between Indigenous leaders and government administrators (Teixeira 2010), is interpreted as 'interculturality', when, in fact, it reproduces the same type of asymmetry and tension which it seeks to undo.

We would like to stress that we do not intend to use the ethnographic evidence narrated in these different situations to blame individuals. This is not what our set of ethnographic data reveals. Instead, we propose to carefully consider these situations by focusing on the overlapping ties between people and institutions and their power effects. In this sense, the lecturer disregarded the Munduruku not because she was a bad public servant or a bad health professional, but because she could do so in a structural sense. It allowed her to more quickly observe boring protocol which she may not have wanted to carry out herself, as evidenced by her impatience during the event. At any rate, we are not in the realm of intentionalities, but of a politics of relations that bears a historical depth that affects everyone.

It seems clear to us, at this juncture, that an act of care is an act of power, and relations of care are no less political, nor do they convey an aura that transcends daily conflicts. Care is therefore an act of managing space, time and the lives of others. We are not here proposing a naturalized view of care, as if the political dimension contaminated relations of care. Instead, we see the political dimension as an ineluctable aspect of care, one which reveals forms of association that demand our investigation. This theoretical stance allows us to better comprehend this specific relation of power - a development that we will explore in the conclusion.

\section{Concluding remarks: new configurations of power and violence, new citizenships}

There are numerous studies of health care in the special Indigenous sanitary districts. They adopt different approaches and investigate different themes: traditional medicine, Indigenous health and sanitation agents, differential care, etc. (Buchillet 1991, 1995, 2004, Garnelo 2003, Erthal 2003, Langdon \& Garnelo 2004, Dias-Scopel 2005, Novo 2010, Dias da Silva 2014 e 2017b). There are likewise numerous studies of Indigenous participation in public policies: its dilemmas and challenges (Cruz 2011; Ribeiro de Almeida 2010; Teixeira et al. 2013; Palheta 2015), the conferences (Garnelo 2002; Teixeira 2010); the councils and councillors (Langdon \& Garnelo 2004; Garnelo \& Sampaio 2005; Ferreira 2012). Acknowledging the excellence of these studies, we have sought to articulate these two themes so as to reveal new meanings. Our research has thus addressed the violence characteristic of these two sets of situations, and their possible connections and political developments.

To conclude, we align our analysis with a delicate reflection, which we hope is not misconstrued by the reader. We do not intend to deauthorize policies of social participation, and we share their democratic aims ${ }^{11}$. Our aim in this article is to contribute to an understanding of the limits and possibilities of this new configuration of power, which seeks to produce citizens capable of acting in their own benefit by participating and collaborating with government policies. This is a sort of civic version of the Christian teaching that "you should not give fish to a man, but teach a man to fish". From this angle, the citizen must be a new subject of power (the participatory citizen), and he or she must be produced as such: "taught", "capacitated", and so many other terms that smooth over the subjection and moulding that is required for this process to be successful. Thus, the dichotomy between the subject and object of power loses meaning, since the production of the former depends on the constitution of the latter: the subject who participates (subject of power) must learn to be a citizen (object of power) who negotiates, converses, and agrees, rather than one who fights and confronts. In 1910, when the SPI was created, the Minister for Agriculture, Industry and Commerce said that the agency would "constitute catechism in new terms, conferring on it a Republican face" (in Souza Lima 1987: 26). Today, it is not just a matter of replacing the word 'catechism' with 'protection'. Today, the magic of

11 While we were preparing this article for publication, the very structure of social participation and of Indigenous healthcare in Brazil became threatened with extinction by the government of president Jair Bolsonaro. 
transforming direct violence into symbolic violence is no longer based on fraternal protection. It has acquired a new dynamic: that of the utopia of the distribution of power and differential rights. Furthermore, the dispute over legitimacy is made more complex by the multiplication of mediators (Indigenous and non-Indigenous specialists, Indigenous leaders and their allies, various bureaucrats, professional and occasional politicians) who are frequently trapped in a grammar of accusations which, in the case of healthcare, is rarely made explicit in accusations of violence, as we have been arguing throughout this article.

If Indigenous participation expanded networks and channels of articulation, taught them new political strategies, familiarized them with discourse registers that effect Indigenous healthcare, what we have been arguing in this article is that these effects are contained by the formal rules of "social control" which do not grant the power of decision (or veto) to Indigenous peoples, and which appear to weaken political confrontation by the predominant moral tune of "conciliation". The presence of Indigenous candidates in the 2018 elections, including the election of the first Indigenous congresswoman in the history of Brazil ${ }^{12}$, suggests an understanding that the challenge at hand involves deepening the conditions for political participation. This creates tensions in institutionalized spaces of social participation, seeing as the incentive to participate in government policies and in the management of Indigenous healthcare do not result in an improvement in the living conditions of these citizens - now transformed into 'populations', with their indicators and statistics but, rather, generate and multiply the very act of participating. This process, in turn, construe as a "paradox" or a "police affair" the direct violence that bears the indisputable stamp of national development, where state agents act directly and through omission, which is exercised and combined with participatory power. Structural violence is here processed not only by the effacement of the historical connections with tutelary domination, but mainly by the transformation of these connections into "contradictions" of the democratic process - contradictions which must be corrected (at least until recently) by the creation of further spaces for participatory democracy, spaces which abide by the self-same rules.

At the same time the relation between professional neglect and the precarity of the living conditions of Indigenous peoples in healthcare practices, which has marked indigenism in Brazil since the SPI, are perpetuated under the veil of practices of improvisation (Dias da Silva 2010). Such practices characterize the work of health professionals in Indigenous lands, whether as a way of coping with material precarity or in the interactional dynamics that make explicit the deauthorization of the other. The universe of benevolence that is inscribed in the rhetoric of daily care, and which is the idiom par excellence of the health post, traverses the rhetoric of social participation and is maintained as a form of violent interaction that disregards and distorts the demands of the other in the management of this care. Taking violence in Indigenous healthcare as simultaneously significant action, structure (of power and of the material conditions of existence) and history has enabled us to map continuities between distinct temporalities and spacialities. In the temporal axis, we can apprehend the relation between the turn of the 2oth century and the recent period of (1) participatory democracy and (2) universal and differential rights to healthcare. We have thus sought to articulate yesteryear's legally incapable Indian to the contemporary subject (who is subject to) participation. But we have likewise sought to connect the past Indian targeted by selfless acts of healthcare (and by successive sanitary campaigns), object of the destructive effects of contact, with the contemporary Indian who bears a differential right to healthcare, object of the effects of the precarity of the structure of healthcare in villages and of the strategies of neglect and the avoidance of conflict (through the manipulation of authority and biomedical procedure). In the spatial axis, we have identified (but not investigated) the links between the politics of Indigenous inclusive participation

12 Joênia Wapichana became a congressomwan for the state of Roraima. Her term began in 2019. 
and the model of economic development that excludes them ${ }^{13}$; as well as between this politics (and its power vacuum) and the relations of power between healthcare professionals and Indigenous patients.

Returning to the question of censorship, our hypothesis is that, in the recent arena of democratic politics in Brazil, the effect of censorship is expressed in an inability to concede that participation, in the form of dialogue and co-responsibility, is not a sharing of power, but an instrument of domination; it is a type of structural and symbolic violence in which conflict and the dispute over legitimacy cannot be made explicit, because of the over-arching consensus around the value of participation and social control in the field of Indigenous health. And this is a field in which indigenism meets sanitary policies, tutelary powers meet biomedical power in democratic contemporaneity. These are the elements that guide the permanent production of new Indigenous citizenship since the mid-1980s: a participative citizen, with differential rights. It is with these citizens that, in an apparent paradox, the government, through financial resources and training programmes, seeks to share the exercise of power through varied forms of collaboration. In this way, new configurations of power are constituted in which, in Cruikshank's Foucauldian reading, "The citizen is an effect and an instrument of political power rather than a participant in politics" (1999:5).

Yet it is not only participative citizenship that cannot be made explicit as a singular process for producing subjects and subjection; neither can care be unveiled as a process for producing quotidian violence. In the local activities of healthcare, our second area of focus, disjunction (which itself conceals structural violence) takes place in the daily management of inattention to healthcare in the villages. This negligence in turn engenders suffering and routine deaths through an unspectacular process of exclusion, of transforming inadmissible physical violence (deaths and malnutrition, waterborne diseases, parasitosis) into habits of a politics of healthcare which, nonetheless, is deemed more or less successful in "cultural", "logistical" or "legal" terms. In this way, it is difficult to situate those who are responsible for violence in healthcare.

All of this is unsaid during normal times, but in moments of crisis and distrust they seep through the censorship of the political game of Indigenous healthcare. It is only by carefully examining the interactions experienced in the two contexts articulated here (political negotiations in social control and healthcare in the villages), situating them in the long-term historical processes that constitute them (indigenism and sanitary policies), and referring them to the exacerbation of physical violence in the last ten years ${ }^{14}$, that we can comprehend the complaints, the conflicts (experienced in discourse, in the management of medication, in performic protests, etc.) and the negotiations in Indigenous healthcare as expressions and weapons of a struggle for power and domination that is metamorphized as collaboration, participation, attention, care.

Through the different situations we have investigated, we have thus sought to apprehend structural violence and its symbolic expression in their systematic nature in the everyday relations of healthcare and in the political negotiations of Indigenous health policies, both in the material asymmetries of power and in the distortions of meaning. They constitute a double transfiguration in which: conflicts are avoided, contained and hidden by various procedures institutionally activated by health professionals situated in the villages; and the fragility of "social control" is attributed mainly to the personal characteristics of legitimate authority figures (coordinators of the DISEI, Minister of Health, President of the Republic, etc.) who do not respect decisions reached through dialogue. These understandings erase the mediating violence, which, like a grammar, is incorporated to the conditions of the possibility of the interventions that are questioned and debated in Indigenous healthcare. Reflecting on some of the rules and tendencies that emerge as dominant, but which remain implicit, is a way of making them known. We thereby convey the interrogation of tacit conditions, of presuppositions

\footnotetext{
13 There are a number of anthropologists who have explored the double origin of social participation: how the World Bank had intervened in the last decades and the demands of social movements. For the Brazilian case, see Salviani (2010), Bronz (2016), Teixeira (2017), among others.

14 See report produced by the Indigenous Missionary Council (CIMI): https://www.cimi.org.br/observatorio-da-violencia/relatorio-2016/. Viewed on the $08 / 02 / 2018$
} 
(Bourdieu 2003: 50) in Indigenous healthcare. As the anthropologist and Indigenous leader Gersem Luciano ${ }^{15}$ observed, the time is ripe, after the difficulties which gather in the horizon after the 2018 elections, to articulate an ethno-political project that situates Indigenous peoples in the ideas and projections of Brazil being discussed. This project would emerge from the prospects of political and economic risks for and by Indigenous peoples and their capacity to plan for the future through the lens of Indigenous cosmologies.

Received: April 23, 2018

Approved: January 17, 2019

Translated by: Luiz Costa

\section{References}

AROUCA, C.; LIMA, N. T. 2014. "Antropologia e medicina: a saúde no Serviço de Proteção aos Índios (19421956)". In: Carla Teixeira e Luiza Garnelo (orgs.), Saúde indígena em perspectiva: explorando suas matrizes históricas e ideológicas. Rio de Janeiro: Fiocruz. pp 59-84.

ATHIAS, R.; MACHADO, M. 2001. "A saúde indígena no processo de implantação dos Distritos Sanitários: temas críticos e propostas para um diálogo interdisciplinar". Cad. Saúde Pública, 17(2): 425-431.

BOLTANSKI, L. 1979. As classes sociais e o corpo. São Paulo: Graal.

BOURDIEU, P. 2002 [1989]. O poder simbólico. Rio de Janeiro: Bertrand Brasil. . 2003. Questões de Sociologia. Lisboa: Fim de Século - Edições. 2009 [1980]. O senso prático. Petrópolis: Editora Vozes.

BRONZ, D. 2016. Nos bastidores do licenciamento ambiental. Uma etnografia das práticas empresariais em grandes empreendimentos. Rio de Janeiro: Ed. Contra Capa.

BUCHILLET, D. 1991. "A antropologia da doença e os sistemas oficiais de saúde". In: . (org.), Medicinas Tradicionais e Medicina Ocidental na Amazônia. Belém: Edições CEJUP. 21-44. . 1995. "Contas de Vidro, Enfeites de Branco e Potes de Malária: Epidemiologia e representações de doenças infecciosas entre os Desana". Série Antropologia, vol.187. Brasília: DAN/UNB. . 2004. "Cultura e saúde pública: reflexões sobre o Distrito Sanitário Especial Indígena do Rio Negro". In: J. Langdon \& L. Garnelo (orgs.), Saúde dos povos indígenas. Reflexões sobre antropologia participativa. Rio de Janeiro: Contra Capa/ABA. 42-54.

CARDOSO, M. 2004. "Políticas de saúde indígena e relações organizacionais de poder: reflexões decorrentes do caso do Alto Xingu". In: J. Langdon \& L. Garnelo (orgs.), Saúde dos povos indígenas. Reflexões sobre antropologia participativa. Rio de Janeiro: Contra Capa Livraria/ Associação Brasileira de Antropologia. 155-170.

COSTA, D. C. 1987. "Política Indigenista e assistência à saúde. Noel Nutels e o Serviço de Unidades Sanitárias Aéreas". Cadernos de Saúde Pública, 4(3): 388-401.

CRUIKSHANK, B. 1999. The will to empower: Democratic citizens and other subjects. Ithaca, NY: Cornell University Press. 
CRUZ, K. 2011. "Estratégias Indígenas de Particip(Ação) na Saúde Indigenista. Jornada Internacional de Políticas Públicas”. http://www.joinpp.ufma.br/jornadas/joinpp2011/CdVjornada/JORNADA_EIXO_2011/ POLITICAS_PUBLICAS_PARA_OS_TERRITORIOS_POVOS_E_COMUNIDADES_TRADICIONAIS| ESTRATEGIAS_INDIGENAS_DE_PARTICIP_ACAO_NA_SAUDE_INDIGENISTA.pdf Access: 22/01/2018. CUNHA, N. V. 2002. "O espírito do sanitarismo": narrativas de profissionais da Saúde Pública dos anos 30 . Tese (Doutorado em Antropologia) Departamento de Sociologia e Antropologia/UFRJ.

DIAS DA SILVA, C. 2010. Cotidiano, saúde e política. Uma etnografia dos profissionais da saúde indígena. Tese (Doutorado em Antropologia), Departamento de Antropologia, Universidade de Brasília. . 2014. "De improvisos e cuidados: a saúde indígena e o campo da enfermagem". In: Jean Langdon e Luiza Garnelo (Orgs.), Saúde indígena em perspectiva: explorando suas matrizes históricas e ideológicas (Coleção Saúde dos Povos Indígenas). Rio de Janeiro: Editora Fiocruz. 181-212.

. 2017a. "A construção da autoridade benevolente via razão humanitária: política de saúde indígena e biolegitimidade”. In: Cristina Dias da Silva e Silvia Guimarães (Orgs.), Antropologia e saúde: diálogos indisciplinados. Juiz de Fora: EdUFJF. 43-65.

. 2017b. "Como terceiros: reflexões entre agentes indígenas de saúde no Alto Tapajós (PA)". In:

Carla Teixeira, Carlos O. do Valle \& Rita C. Neves (Orgs.). Saúde, mediações, mediadores. Brasília: ABA Publicações/ Natal: EDUFRN. 217-243.

DIAS DUARTE, L. F. 1986. Da vida nervosa nas classes trabalhadoras urbanas. Rio de Janeiro: Jorge Jahar Editor. DIAS-SCOPEL, R. P. 2005. O agente indígena de saúde XOKLENG: $O$ mediador entre a comunidade indígena e os serviços de atenção diferenciada à saúde. Dissertação (mestrado em Antropologia) PPGAS/UFSC.

ERTHAL, R. M. C. 2003. "A formação do agente indígena de saúde Tikúna no Alto Solimões: uma avaliação crítica”. In: Carlos Coimbra; Ricardo Ventura Santos e Arturo Escobar (orgs.), Epidemiologia e saúde dos povos indígenas no Brasil. Rio de Janeiro: Editora Fiocruz/ABRASCO. pp.197-215.

FARMER, P. 2004. "An anthropology of structural violence". Current Anthropology, 45(3): 305-325.

FERREIRA, L. B. 2010. O Controle Social no Subsistema de Atenção à Saúde Indígena: uma reflexão bioética. Tese (Doutorado em Bioética) - Faculdade de Ciências da Saúde, Universidade de Brasília.

FERREIRA, L. O. 2013. "A emergência da medicina tradicional indígena no campo das políticas públicas". História, Ciências, Saúde-Manguinhos (Impresso), 20: 203-219.

FOUCAULT, M. 1971. "Orders of discourse". Social Science Information, 10(2) :7-30.

GEERTZ, C. 1985. Local knowledge. New York: Basic Book.

GARNELO, L. 2002. "Controle Social na Saúde Indígena: reflexões sobre a III Conferência Nacional de Saúde Indígena”. In: 23a Reunião Brasileira de Antropologia, Fórum de Pesquisa Política de Saúde e a Interveção Antropológica, Gramado. Mimeo.

. 2003. Poder, hierarquia e reciprocidade: saúde e harmonia entre os Baniwa do Alto Rio Negro. Rio de Janeiro:

Editora Fiocruz.

. 2004. Política de saúde dos povos indígenas no Brasil: análise situacional do período 1990 a 2004. Porto Velho: UFRO/ Rio de Janeiro: Fundação Oswaldo Cruz.

.; SAMPAIO, S. 2005. "Organizações indígenas e distritalização sanitária: os riscos de "fazer ver" e

"fazer crer" nas políticas de saúde”. Cadernos de Saúde Pública, 21(4): 1217-1223.

HERZFELD, M. 2008. Intimidade cultural. Poética-social no estado-nação. (Coleção Perspectivas do homem)

Lisboa: Edições 70.

HOCHMAN, G. \& SILVA, R. 2014. "Campanhas públicas, populações (quase) invisíveis: endemias rurais e indígenas na saúde pública brasileira”. In: Carla Teixeira e Luiza Garnelo (orgs.), Saúde indígena em perspectiva: explorando suas matrizes históricas e ideológicas. Rio de Janeiro: Fiocruz. pp. 85-106.

KROHN-HANSEN, C. 1994. "Anthropology of violent interaction”.J. Anthropological Research, 50(4): 367-381. 
LANGDON, E. J.; GARNELO, L. 2004. (Orgs.). Saúde dos Povos Indígenas: reflexões sobre antropologia participativa. Rio de Janeiro: Contra Capa.

LANGDON, E. J. 2004. “Uma avaliação crítica da atenção diferenciada e a colaboração entre antropologia e profissionais de saúde”. In: E. J. Langdon \& L. Garnelo (orgs.), Saúde dos povos indígenas. Reflexões sobre antropologia participativa. Contra Capa: ABA. 25-41.

LIMA, N. T.; HOCHMAN, G. 200o. "Pouca saúde, muita saúva: os males do Brasil são... discurso médicosanitário e interpretação do país”. Ciência e Saúde Coletiva, 5(2): 313-332.

LOYOLA, M. A. 1984. Médicos e curandeiros: conflito social e saúde. São Paulo: Difel.

MAGALHÃES, E. D. 2001. O Estado e a saúde indígena: a experiência do Distrito Sanitário Yanomami. Dissertação (Mestrado em Serviço Social) SER/UNB.

MARQUES, I. S. F. 2003. A política de atenção à saúde indígena: a implantação do Dsei de Cuiabá-MT. Dissertação. (Mestrado em Saúde Pública) Rio de Janeiro: Escola Nacional de Saúde Pública, Fiocruz.

NOVO, M. P. 2010. Os Agentes Indígenas de Saúde do Alto Xingu. Brasília: ABA/Paralelo 15.

PALEY, J. 2002. “Toward an anthropology of democracy”. Annual Review of Anthropology, 31:469-496.

PALHETA, R. P. 2015. Política Indigenista de Saúde no Brasil. São Paulo: Cortez.

RIBEIRO DE ALMEIDA, F. V. 2010. "O índio sabe, o índio faz: os dilemas da participação indígena nas políticas públicas”. In: C. Souza et al. (orgs.), Povos Indígenas, projetos e desenvolvimento II. Brasília: Paralelo 15; Rio de Janeiro: LACED. 177-185.

RICHES, D. (ed.). 1986. The Anthropology of Violence. Oxford: Basil Blackwell.

ROCHA, E. 2007. Uma etnografia das práticas sanitárias no Distrito Sanitário Especial do Rio Negro. Dissertação.

(Mestrado em Sociedade e Cultura na Amazônia). Manaus: Universidade Federal do Amazonas.

SALVIANI, R. 2010. "Desenvolvimento, antropologia e 'participação”. Anuário Antropológico/2009 -1: 227-261. SCHUTZ, A. 1979. Fenomenologia e Relações Sociais. Helmut Wagner (org.). Rio de Janeiro: Zahar Editores.

SILVA, F.H.P. 2017. "Por dentro e por fora do Estado": estratégias e desafios no processo político de constituição do movimento indígena no Brasil contemporâneo. Dissertação (mestrado em Antropologia Social), Departamento de Antropologia, Universidade de Brasília.

SMILJANIC, M. I. 2008. "Da observação à participação: Reflexões sobre o ofício do Antropólogo no contexto do Distrito Sanitário Yanomami”. Série Antropologia, vol. 417. Brasília: DAN/UNB.

SOUZA LIMA, A. C. 1995. Um grande cerco de paz. Petrópolis: Vozes.

. 1987. "Sobre Indigenismo, Autoritarismo e Nacionalidade: Considerações sobre a constituição do discurso e da prática da proteção fraternal no Brasil”. In: João Pacheco de Oliveira (org.), Sociedades indígenas e indigenismo no Brasil. 1ạ ed. Rio de Janeiro/São Paulo: UFRJ/Marco Zero. pp. 149-214.

. 2002a. "Diversidade cultural e política indigenista no Brasil". Tellus, 3: 11-31.

2002b. "Tradições de conhecimento para gestão colonial da desigualdade: reflexões a partir da administração indigenista no Brasil”. In: C. Bastos; M. Almeida; B. Feldman-Bianco (orgs.), Trânsitos coloniais: diálogos críticos luso-brasileiros. Lisboa: Imprensa de Ciências Sociais pp. 151-172.

. 2002c. "Sobre gestar e gerir a desigualdade: pontos de investigação e dialogo". In: Gestar e Gerir: estudos para uma antropologia da administração pública no Brasil. Rio de Janeiro: Relume Dumará (Coleção Antropologia da Política). 11-22.

. 2015. "Sobre tutela e participação: povos indígenas e formas de governo no Brasil, séculos XX/XXI." Mana (UFRJ. Impresso), 21(2): 425-457.

STEWART, P.; STRATHERN, A. 2002. Violence: Theory and Ethnography. London/ New York: Continunm. TEIXEIRA, C. 2010. "Autonomia em Saúde Indígena: sobre o que estamos falando? Anuário Antropológico, 2010(1): 99-128. 
. 2010. "A produção política da repulsa e os manejos da diversidade na saúde indígena brasileira".

Revista de Antropologia, 55(2): 567-608.

. 2017. "Participação social na saúde indígena: a aposta contra a assimetria no Brasil?" Amazônica, Ver.

Antropol. (Online), 9(2):716-733.

. et al. 2013. "Controle Social na Saúde Indígena: limites e possibilidades da democracia direta".

Tempus: Actas de Saúde Coletiva, 7: 97-115.

VELHO, O. 2009a. Frente de Expansão e Estrutura Agrária: estudo do processo de penetração numa área da

Transamazônia [online]. Rio de Janeiro: Centro Edelstein de Pesquisas Sociais.

. 2009b. Capitalismo Autoritário e Campesinato: um estudo comparativo a partir da fronteira em movimento [online]. Rio de Janeiro: Centro Edelstein de Pesquisas Sociais.

VERANI, C. B. L. 1999. "A política de saúde do índio e a organização dos serviços no Brasil”. Boletim do MPEG:

Série Antropologia, 15(2): 171-192.

WEBER, M. 1999. Economia e sociedade: fundamentos da sociologia compreensiva. Brasília, DF: Editora

Universidade de Brasília; São Paulo: Imprensa Oficial do Estado de São Paulo.

\section{Carla Costa Teixeira}

University of Brasilia, Brazil

https://orcid.org/oooo-0002-3792-9687

Author's e-mail: carla.c.teix@gmail.com

\section{Cristina Dias da Silva}

University of Juiz de Fora, Brazil

https://orcid.org/oooo-0001-8360-5272

Author's e-mail: cristinabaltor@gmail.com 